\title{
Terrorist campaigns and the growth of the Muslim population: a reply
}

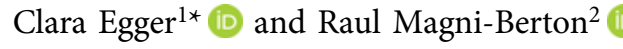 \\ ${ }^{1}$ International Relations and International Organization Department, Faculty of Arts, University of Groningen, Groningen, \\ The Netherlands and ${ }^{2}$ Univ. Grenoble-Alpes, Sciences Po Grenoble, PACTE, Saint-Martin-d'Hères, France \\ ${ }^{\star}$ Corresponding author. E-mail: c.m.egger@rug.nl
}

(Received 25 April 2021; revised 10 May 2021; accepted 18 May 2021; first published online 8 July 2021)

\begin{abstract}
A recently published paper in this journal (Choi, 2021) establishes a statistical link between, on the one hand, Islamist terrorist campaigns - including terrorist attacks and online propaganda - and, on the other the growth of the Muslim population. The author explains this result by stating that successful campaigns lead some individuals to convert to Islam. In this commentary, we intend to reply to this article by focusing on the impact of terrorist attacks on religious conversion. We first show that Choi's results suffer from theoretical flaws - a failure to comprehensively unpack the link between violence and conversion and methodological shortcomings - a focus on all terrorist groups over a period where Islamist attacks were rare. This leads us to replicate Choi's analysis by distinguishing Islamist and non-Islamist terror attacks on a more adequate timeframe. By doing so, we no longer find empirical support for the relationship between terror attacks and the growth of the Muslim population. However, our analyses suggest that such a hypothesis may hold but only in contexts where the level and intensity of political violence are high.
\end{abstract}

Key words: Empirical analysis; Islamist political violence; religious conversion; terrorism

\section{Introduction}

Political violence - of which terrorism is one of the most visible manifestations - has attracted a lot of scholarly attention, not only because of its salience, but also because, from a scientific point of view, the underlying logic of terrorism is intriguing especially for individual perpetrators (see, among others, Pape, 2003; Bongar et al., 2006; Crenshaw, 2007). The latter sacrifice their life - or at the very least their freedom as they are always caught - for rather uncertain gains. Deadly attacks rarely impact powerful actors able to access the requests of perpetrators in a direct way and generate dramatic retaliation on the people perpetrators pretend to serve. Yet, despite these puzzling aspects, terrorism remains an appealing course of political action for many individuals around the globe. Within this sizable literature, the most consensual logic behind terrorism is readable through the strategic agenda of the organizations driving or supporting the attacks. Terrorist tactics are used to signal the destructive capacity and power of an organization. This signaling intends to, on the one hand, strengthen its bargaining power $v i s-\grave{a}$-vis the targeted authority and, on the other rally to its cause radical individuals in search of a credible structure to achieve their political objectives (Crenshaw, 2007).

Building on the potential appeal of successful terrorist organizations, Choi (2021) has recently tried to generalize this logic to the case of Islamist terrorism, the most prominent manifestation of terrorism since the past few decades (University of Maryland, 2019). In a piece recently published in this journal, Choi argues that terrorist campaigns - including deadly attacks and propaganda - increase the number of people who convert to Islam and, ultimately, the size of the Muslim population. The impact of this

(C) The Author(s), 2021. Published by Cambridge University Press. This is an Open Access article, distributed under the terms of the Creative Commons Attribution-NonCommercial-NoDerivatives licence (https://creativecommons.org/licenses/by-nc-nd/4.0/), which permits noncommercial re-use, distribution, and reproduction in any medium, provided the original work is unaltered and is properly cited. The written permission of Cambridge University Press must be obtained for commercial re-use or in order to create a derivative work. 
mechanism is, according to the author, so massive that it makes him speak of a 'fourth phase of Islamization in the wake of terrorist attacks and online propaganda' (Choi, 2021:3) following three historical pathways of diffusion of the Islamic faith - conquest, trade, and immigration.

This comment piece intends to critically review the argument and research findings of the author in light of their potential importance for the analytical study of terrorism. To do so, we leave aside the role of online propaganda to focus on his most original result - the connection between successful domestic terror attacks and the massive recruitment of individuals into the ideology of the perpetrator. The reason for this focus is that propaganda, whether online or offline, violent or peaceful, leads people to join various movements is obvious. That propaganda triggers conversion is not the subject of scholarly debates, but the magnitude of its effects is - an aspect the author neglects. Moreover, the focus on online violent propaganda - that the paper does not directly measure - is not the most relevant or original in the specific case of Islamism. Peaceful proselytism - da'wah - focusing on humanitarian and social activities has been found to be more effective at producing conversions into Islam than online violent ones (Rambo and Farhadian, 2014). This has, for example, been a strategy followed by the Muslim Brotherhood not only in Egypt, but also in a wide range of non-predominantly Muslim societies (Ghandour, 2002). The organization mainly relied on the provision of social services to build support for Islamism (for a comparative analysis, see Grynkewich, 2008).

In contrast, the analysis of the impact of terrorist attacks on conversion is much more puzzling. If there was a direct, causal, link between engaging in violence and triggering support for one's cause, then the logic behind the appeal of terrorism is much less of a scientific enigma as terrorism would be used as a recruitment strategy. Although ambitious and original, history does not seem to strongly support this argument. Far left terrorism had, for example, little success in galvanizing militant support. In Turkey, attacks of the Marxist PKK have been found to increase votes for right-wing parties that are more repressive against terrorism (Kibris, 2011). Similarly, in Europe, an increase of votes for far-right political parties precedes, not follows, far-right inspired terrorist attacks (Varaine, 2020b). With regard to separatist ideologies, terrorist attacks from the ETA - a Basque violent secessionist movement - either had no or a negative impact on electoral support to the separatist political parties in the Basque region of Spain (De la Calle and Sanchez-Cuenca, 2013; Balcells and Torrats-Espinosa, 2018). However, this could be different for Islamism, and Choi provides some empirical clues to support such a hypothesis.

However, a careful reading of Choi's article reveals some major flaws that undermine the reliability of his results. Our commentary addresses such flaws in three sections. The first focuses on the theoretical aspects of the paper. Although Choi bases its theoretical argument on a well-documented premise - that terror attacks are a way of engaging radical individuals into violence - there are no theoretical reasons to believe that this mechanism - leading some individuals to convert - can have an impact on the overall Muslim population. Radical individuals are an extreme fringe of militants and terror attacks are also likely to lead some moderate Muslims to convert to another religion or to distance themselves from religious practice. Hidden variables likely to explain the expected positive relationship should also be accounted for to conclude in the way the author does. Second, we discuss two central issues of Choi's empirical design, the fact that his main independent variable captures all types of terrorist attacks and his focus on a timeframe when Islamist attacks were rare. This leads us to replicate his results in the third section by focusing only on Islamist deadly attacks. Our results show that there is no significant association between Islamist attacks and the growth of the Muslim population. In line with existing theories, we however show that in some specific contexts - characterized by high levels of violence and terrorist attacks perpetrated by various competing groups - Islamist terror attacks can lead to a growth of the Muslim population. However, in more peaceful contexts, Islamist terrorism is likely to have a rather negative impact on the number of Muslims.

\section{An incomplete theoretical account of the impact of terror attacks on Muslim believers}

In what follows, we discuss Choi's argument according to which terror attacks lead a large number of people to convert to Islam. Although the fact that radicals are attracted into Islamism receives support 
in the extant literature, we show that Choi's generalization of this finding to the overall population of Muslim is flawed by a failure to account for possible exit trajectories and alternative mechanisms linking violence with the growth of the Muslim population.

\subsection{Terror attacks as a signaling strategy to a small fringe of radicals}

Strategic accounts of terrorism (Pape, 2003; Crenshaw, 2007) have established that terrorist tactics are used to signal the power and resources of violent organizations. A successful terror attack signals the ability of such organizations to impose strong costs on its opponents and to stand retaliation in the form of asymmetrical warfare (Polo and Gleditsch, 2016). This signal is likely to have a mobilizing impact on people who sympathize with the agenda of the group, leading them to join its ranks (Kydd and Walter, 2006). Signaling is not, however, a primary driver of engagement in violence. Numerous studies have shown that opportunity costs and political grievances - associated with the experience of discriminatory policies or violence - are central root causes of individual mobilization in violence (Karagiannis, 2012). Yet, by perpetrating attacks, terrorist organizations make visible how such grievances can be ideologically framed. This pattern has been documented by Roy (2017) in his analysis of the biographical trajectories of 140 contemporary European perpetrators of Islamist political violence. Perpetrators are typically attracted by violence, before being Muslim. They often convert to Islam as Islamism legitimates their violent actions and provides a sense of belonging to a group. Roy also found evidence that some of them have been inspired by past terrorist attacks.

These studies, however, are carried out on a very specific and small fringe of people - those who undertake violent action in support of Islamist groups. In contrast, the impact of such conversions on the growth of the overall Muslim population is likely to be hardly visible. To hold, attacks should make violent Islamism attractive for a larger population including, for example, people exhibiting high degrees of tolerance for political violence without necessarily being willing to engage in it. One of the few studies providing an empirical account of the connection between on the one hand support for terrorism and, on the other conversion to Islam on the basis of large- $N$ international surveys shows that, in some Western European countries, individuals who have recently increased their practice of Islam are more likely to justify terrorism (Egger and Magni-Berton, 2021). Such a relationship only holds for Belgium, France, Germany, and the United Kingdom among the 21 countries of the research sample. These countries are the ones providing the largest share of foreign fighters to the Islamic State in Iraq and Syria (Benmelech and Klor, 2020) and are regularly targeted by homegrown terrorism. This study hence seems to confirm that Islamism is an appealing ideology for radicals, potentially leading a large number of people to convert to Islam.

\subsection{A failure to comprehensively account for the link between terror attacks and religious beliefs}

Overall, some research supports the argument that terror attacks can induce some individuals in some countries to get closer to the Muslim faith. Inferring from these micro-level mechanisms, macro-level trends is, however, hazardous as we have no evidence that such trajectories can unfold on a massive scale. In doing so, however, Choi's (2021) reasoning suffers from three main flaws.

The first consists of overestimating the phenomenon at stake. Studies concur that people brought to Islam because of a support of violent Islamist agendas are a minority. Seeing - as Choi does - in the behavior of a fringe of individuals, the central driver of the 'fourth wave of Islamization' (Choi, 2021: 4) without clearly demonstrating why such trajectories are massive severely limits the credibility of such an argument.

The second, more fundamental flaw, lies in isolating this possible scenario and neglecting other plausible ones that may yield opposite results. Although terror attacks may lead people to convert to Islam, they are also likely to move others - moderate or secular believers - away and to trigger, in some extreme cases, conversion into another religion. This distancing can be fueled by many different drivers, be they ethical concerns, decreased feelings of group belonging, a rejection of violent 
acts, a fear of being targeted by discrimination, violence or negative attitudes toward Islam. Combined, the two mechanisms would not affect the size of the overall population of Muslim believers. Although very plausible, very few evidence of this opposite mechanism can be found probably because conversions are easier to trace than distancing from religion that may not be recorded. Moreover, the increased scholarly interest in minority militant Islam has led scholars to disregard less spectacular research topics, such as the attitudes and behaviors of secular or moderate Muslims often studied as subjects of counter-terrorism policies but not as agents of change. Yet, some clues can be found of a demobilizing impact of attacks. For example, in their study on more than 13 Twitter accounts linked to the Islamic State (IS), Barceló and Labzina (2020) find that the number of followers of IS-related Twitter accounts significantly decrease in the aftermath of the attacks. Therefore, even among more radical people, terrorist events produce more disengagement than mobilization. A survey administered to Swedish Muslims in the aftermath of the 9/11 attacks reports an increase of conversations on Muslim identity leading to an increased visibility of secular readings of Islam beliefs (Sander, 2006). Assuming that this scenario exists, terror attacks should only increase the overall number of Muslims in contexts where attacks inspire more people than they repel.

All in all, and despite the existence of an impact of terror events on individual conversion to Islam, it is unlikely that terror events significantly increase the population of Muslims at the aggregated level. Other consequences are much more likely to be plausible and are hardly discussed in Choi's paper. For example, we can reasonably expect that terrorism alters the internal distribution of Muslim schools and branches. Attacks could trigger a radicalization of Muslim believers due to a conversion of non-Muslim radicals and to a distancing of believers opposed to violence. Moreover, in contexts where Muslims suffer from persecution, terrorism may produce more supporters than condemners.

Third, Choi never rules out alternative explanations that are more likely to explain a positive statistical association between terror events and the growth of Muslim population than his own theory does. Two alternative mechanisms especially appear to have a strong explanatory power. The first lies in the impacts of discriminatory policies. Discrimination against minority groups is not only a breeding ground for violence (Piazza, 2011, 2012; Ghatak, 2016; Ghatak and Prins, 2017), but also positively influences fertility rate. Discrimination against minorities on the labor market reduces their opportunities for social mobility and some women may prefer motherhood to entering the job market (Poston et al., 2006; Wilson and Kuha, 2018). Discriminatory policies may hence be the hidden factor related to terror attacks and the growth of Muslim population but based on two distinct mechanisms. Similarly, high levels of Muslim immigration may lead host communities to be appealed by Islam, while increasing the size of the extreme fringe of violent Islamist and the likelihood of homegrown terror attacks.

The second rests on reverse causality. Assuming that the likelihood of being exposed to violent Islamist ideologies is higher for someone raised in the Muslim faith than for a convert, we can also expect that the larger the population of Muslims, the higher the likelihood that some of the most radical militants will engage in terrorism. This is the theoretical reason why many empirical studies include the size of the Muslim population (relatively or in an absolute manner) as a control variable in their model specifications. In most of the cases, the coefficient is significant (Choi and Piazza, 2017; Egger et al., 2020).

Before engaging in theoretical development and interpretation, however, facts have to be firmly established. Is the observed correlation between the growth of Muslim population and terrorist events reliable?

\section{A flawed empirical design}

Having discussed the theoretical grounding of Choi's argument and the lack of arguments suggesting it could be generalized to the overall population of Muslims, we now turn to the evaluation of his research design to discuss two central flaws that prevent from drawing any meaningful results from his analysis. 
The key innovation of the design surely lies in the operationalization of the dependent variable which counts the percentage of Muslims in 152 countries. Such data are precious as existing datasets ${ }^{1}$ do not capture annual variation in the size of religious people that is crucial to understand the time impact of specific events. That is why Choi uses a new dataset originating from the Religious Characteristics of States (RCS) project (Brown and James, 2018). He also compiles yearly data from official government sources and completed his dataset using 25 secondary sources.

In comparison, the variables related to terror attacks suffer from considerable bias. Choi distinguishes between domestic and international terror events, based on the Global Terrorism Database (GTD) (LaFree and Dugan, 2007) and using the approach developed by Enders et al. (2011). This variable, however, does not isolate Islamist attacks. Conceptual and methodological reasons are invoked to justify such choice. Conceptually, Choi claims that 'due to the widespread yet unfounded perception that associates Islam with terrorism, people are likely intrigued by Islam after terrorist attacks. This means that people's perception prevails over the reality of whether terrorist plots are actually executed by Muslims or not, so a majority of terrorist attacks likely contribute to an increase in Muslim converts and populations' (2021: 8). This could be an acceptable shortcut if the data covered a recent timeframe, characterized by a predominance of Islamist terror attacks globally. ${ }^{2}$ Unfortunately, however, his data focus on the time period ranging from 1970 to 2007 when the most active groups include the Irish Republican Army in the UK, the Revolutionary Armed Forces of Colombia (FARC) in Colombia, the Basque Country and Freedom (ETA) in Spain, the Shining Path (Sendero Luminoso) in Peru, the Kurdistan Workers' Party (PKK) in Turkey, or the Red Brigades (Brigate Rosse) in Italy. All of these groups had a predominant domestic agenda - rooted in secessionist or far-left ideologies - and were mainly seeking political change at the national level. Arguing that the attacks of these groups would be associated with Islam seems to be more based on the author's rather than on any popular perception. Even between 1991 and 2001, when Islamists attack were on the rise but still rare, there is no serious reason to think people associated Islamism with terrorism, especially in places where attacks were perpetrated by other groups. This association became progressively more frequent after 11 September 2001. As a result, Choi's assumption is at best valid for 7 years of a dataset that covers 38 years and the statistical relationship observed with these data cannot be interpreted in the way he does. To do so, the timeframe should be restricted and the seventies and eighties excluded from the analysis. At the very least, the implications of such a choice could have been extensively discussed in the paper.

To assess whether terror attacks lead to massive waves of conversion, it is then necessary to distinguish between Islamist and non-Islamist terror events at a conceptual level. This is certainly cumbersome and creates risks of bias that Choi rightly acknowledges and uses as a second, methodological, argument to justify its choice. Yet, in the GTD a large number of attacks are unattributed to any terrorist organization, making their classification impossible. As a result, Choi's sample is not immune from selection bias as it is estimated that more than 50\% of the GTD's events are unattributed (LaFree et al., 2019: 78). Yet, during the period between 1991 and 2007 more than 300 Islamist terrorist attacks have been identified. They form a strong basis for statistical analyses and allow focusing on events that have the property to be publicly perceived as Islamist. This means that people are more likely to conform to the behavioral assumptions made by the author.

These flaws taken into account, the most interesting result of the paper is the correlation between (the logarithm of) domestic terrorism and the growth of the Muslim population, which remains significant even in the most conservative estimates. In what follows, we take benefit of another dataset to replicate Choi's analyses, this time distinguishing between Islamist and other terrorist incidents. To do so, we first compile the data provided in Egger et al. (2020) that focuses on the timeframe from 1991 to 2007 and appears more appropriate to study Islamist attacks and their impacts. The identification of the ideology of the perpetrating group is based on its name (available in the GTD) combined with an

\footnotetext{
${ }^{1}$ The World Religion dataset of the Correlates of War project only collect such data for every half decade.

${ }^{2}$ Since 2011, 65\% of the deadliest groups are Islamist (LaFree and Dugan 2016) and, according to the Institute for Economics and Peace (2016), the number of attacks perpetrated by Islamic groups have increased of approximately $2,000 \%$.
} 
analysis of public sources compiled by the website of the Terrorism Research and Analysis Consortium (TRAC, 2019) covering more than 4,500 groups. Less active terrorist groups who perpetrated five attacks or less over 1991-2007 are excluded, as no information is available for most of them. Based on this method, 372 Islamist attacks are identified during the period that account for less than 3\% of the total number of terror attacks in the sample. This small percentage corresponds quite well to the reality. For example, in Peru, Sendero Luminoso has been responsible for more than 500 terrorist incidents for the mere year of 1991. Similarly, in 1992, the FARC performed almost 400 attacks in Colombia. In line with common practices, we take the natural logarithm of the number of terrorist attacks to normalize the positively skewed distribution.

Second, we use the exact same control variables than the ones of the original paper. The selection includes the fertility rate and economic growth from the World Bank's World Development Indicators (2017), college education and political instability from Banks' Cross-National Time-Series Data Archive (2010), and a composite democracy index based on the Polity IV dataset. Finally, the presence of civil and interstate wars is collected from the UCDP/PRIO Armed Conflict dataset. Note, however, that in the dataset no interstate conflict is mentioned after $1990 .{ }^{3}$ Other confounding factors, such as inequality or discrimination are neither included nor discussed despite how useful they can be. In particular, increasing inequalities have been found to be associated with both terrorist attacks (Varaine, 2020a; Varaine et al., 2021) and an increase of (low-skilled) Muslim populations (Gould, 2019). Similarly, as already pointed, discrimination impacts both fertility and terrorism. In this commentary, however, we restrict ourselves to using the variables selected by Choi in order not to confuse the impact of a new control variable on the coefficients of interest with the impact of the change we introduced in discriminating between Islamist and non-Islamist terrorist events and in reducing the timeframe of the study. ${ }^{4}$

In replicating Choi's results, we use the main specification he employed, namely a time-series model based on an ordinary least-squares (OLS) regression with country and year fixed effects and cluster-robust standard errors. Using this method, results are very conservative in order to take into account intra-country correlation. Given the lack of control variables, we believe that this is the most appropriate specification to provide initial evidence in support of an alleged link between the growth of Muslim populations and Islamist domestic terrorist attacks. However, we also provide results based on his second empirical approach, the two-limit Tobit specification that has the advantage of treating the percentage as a censored continuous variable (and excluded the predictions that are not comprised between 0 and 100).

\section{A correlation that does not resist a more rigorous design}

Table 1 displays five models. Model 1 is our main estimate. It regresses the growth of the Muslim population on the lagged number of domestic terrorist incidents. We obtain a coefficient significantly different from zero at 5\% level for the period 1970-2007 and including all domestic terrorist attacks.

Models 2-6 restrict the specification for the period 1991-2007 that is the period in which many countries start hearing of - and, for some, experiencing - Islamist terrorism. Note the considerably lower $R^{2}$, especially between countries. The fact that observations per country are now 17 (rather than 38 ) has to be considered as a tentative explanation for this result. Also, the coefficients of the fertility rate and democracy score lose their significance in the time series models but stay significant in the Tobit models.

Interestingly, in models 2-6, the coefficient of domestic terrorist attacks is not different from 0 anymore. This is true in model 2, where all the domestic terrorist attacks are taken into account, in model

\footnotetext{
${ }^{3}$ Choi also includes in some (less conservative) estimates other factors such as the share of youth, mortality rate, migration, family planning, and urbanization. None of the coefficients are significant.

${ }^{4}$ Similarly, in the article, missing observations are filled with information from previous years. This is not the most recommended way of handling missing data and it would at least be appropriate to check whether the results still hold when missing observations are left missing. This does not constitute, however, the most fundamental flaw of Choi's paper design.
} 
Table 1. Effect of domestic terrorist attacks on Muslim populations

\begin{tabular}{|c|c|c|c|c|c|c|}
\hline & $\begin{array}{c}(1) \\
\text { OLS } \\
\text { 1970-2007 } \\
\text { All terrorist } \\
\text { attacks }\end{array}$ & $\begin{array}{c}(2) \\
\text { OLS } \\
\text { 1991-2007 } \\
\text { All terrorist } \\
\text { attacks }\end{array}$ & $\begin{array}{c}\text { (3) } \\
\text { OLS } \\
\text { 1991-2007 } \\
\text { Islamist } \\
\text { attacks }\end{array}$ & $\begin{array}{c}(4) \\
\text { OLS } \\
1991-2007 \\
\text { Other terrorist } \\
\text { attacks }\end{array}$ & $\begin{array}{c}(5) \\
\text { TOBIT } \\
\text { 1991-2007 } \\
\text { Islamist } \\
\text { attacks }\end{array}$ & $\begin{array}{c}(6) \\
\text { TOBIT } \\
\text { 1991-2007 } \\
\text { Other terrorist } \\
\text { attacks }\end{array}$ \\
\hline $\begin{array}{l}\text { Domestic terrorist } \\
\text { attacks }_{i t-1}\end{array}$ & $\begin{array}{l}0.087^{\star \star} \\
(0.041)\end{array}$ & $\begin{array}{c}0.044 \\
(0.036)\end{array}$ & $\begin{array}{c}0.205 \\
(0.130)\end{array}$ & $\begin{array}{c}0.043 \\
(0.036)\end{array}$ & $\begin{array}{c}0.206 \\
(0.163)\end{array}$ & $\begin{array}{c}0.038 \\
(0.037)\end{array}$ \\
\hline Fertility rate rit-1 & $\begin{array}{l}1.002^{\star \star \star} \\
(0.232)\end{array}$ & $\begin{array}{c}0.501^{\star} \\
(0.291)\end{array}$ & $\begin{array}{c}0.482 \\
(0.292)\end{array}$ & $\begin{array}{c}0.501^{\star} \\
(0.291)\end{array}$ & $\begin{array}{l}0.480^{\star \star \star} \\
(0.102)\end{array}$ & $\begin{array}{l}0.498^{\star \star \star} \\
(0.102)\end{array}$ \\
\hline College education $_{i t-1}$ & $\begin{array}{c}-0.372 \\
(0.318)\end{array}$ & $\begin{array}{c}-0.123 \\
(0.496)\end{array}$ & $\begin{array}{c}-0.122 \\
(0.495)\end{array}$ & $\begin{array}{c}-0.123 \\
(0.496)\end{array}$ & $\begin{array}{c}-0.128 \\
(0.086)\end{array}$ & $\begin{array}{c}-0.128 \\
(0.086)\end{array}$ \\
\hline Economic growth $_{i t-1}$ & $\begin{array}{c}0.049 \\
(0.521)\end{array}$ & $\begin{array}{c}0.496 \\
(0.610)\end{array}$ & $\begin{array}{c}0.498 \\
(0.610)\end{array}$ & $\begin{array}{c}0.496 \\
(0.610)\end{array}$ & $\begin{array}{l}0.501^{\star \star \star} \\
(0.167)\end{array}$ & $\begin{array}{l}0.498^{\star \star \star} \\
(0.167)\end{array}$ \\
\hline Democracy $_{i t-1}$ & $\begin{array}{l}0.069^{\star \star} \\
(0.029)\end{array}$ & $\begin{array}{c}0.055 \\
(0.048)\end{array}$ & $\begin{array}{c}0.055 \\
(0.048)\end{array}$ & $\begin{array}{l}0.055 \\
(0.048)\end{array}$ & $\begin{array}{l}0.057^{\star \star \star} \\
(0.012)\end{array}$ & $\begin{array}{l}0.057^{\star \star \star} \\
(0.012)\end{array}$ \\
\hline Political instability $_{i t-1}$ & $\begin{array}{c}0.009 \\
(0.017)\end{array}$ & $\begin{array}{c}-0.009 \\
(0.018)\end{array}$ & $\begin{array}{c}-0.007 \\
(0.018)\end{array}$ & $\begin{array}{c}-0.009 \\
(0.018)\end{array}$ & $\begin{array}{c}-0.007 \\
(0.009)\end{array}$ & $\begin{array}{c}-0.009 \\
(0.010)\end{array}$ \\
\hline Civil war $_{i t-1}$ & $\begin{array}{c}0.157 \\
(0.368)\end{array}$ & $\begin{array}{c}0.203 \\
(0.185)\end{array}$ & $\begin{array}{c}0.209 \\
(0.183)\end{array}$ & $\begin{array}{c}0.203 \\
(0.185)\end{array}$ & $\begin{array}{c}0.211 \\
(0.235)\end{array}$ & $\begin{array}{c}0.206 \\
(0.235)\end{array}$ \\
\hline Interstate war $_{i t-1}$ & $\begin{array}{l}0.521^{\star \star \star} \\
(0.178)\end{array}$ & & & & & \\
\hline Constant & $\begin{array}{l}21.403^{\star \star \star} \\
(4.261)\end{array}$ & $\begin{array}{l}21.776^{\star \star \star} \\
(5.741)\end{array}$ & $\begin{array}{l}21.882^{\star \star \star} \\
(5.713)\end{array}$ & $\begin{array}{l}21.780^{\star \star *} \\
(5.739)\end{array}$ & $\begin{array}{c}2.147 \\
(1.460)\end{array}$ & $\begin{array}{c}2.124 \\
(1.460)\end{array}$ \\
\hline \multicolumn{7}{|l|}{$R^{2}$} \\
\hline Within & 0.17 & 0.09 & 0.09 & 0.09 & & \\
\hline Between & 0.11 & 0.00 & 0.01 & 0.01 & & \\
\hline Overall & 0.10 & 0.00 & 0.00 & 0.00 & & \\
\hline Pseudo- $R^{2}$ & & & & & 0.69 & 0.69 \\
\hline Country fixed effects & Yes & Yes & Yes & Yes & Yes & Yes \\
\hline Year Fixed effects & Yes & Yes & Yes & Yes & Yes & Yes \\
\hline Obs. & 4795 & 2281 & 2281 & 2281 & 2281 & 2281 \\
\hline
\end{tabular}

Standard errors are in parentheses.

${ }^{\star \star \star} P<0.01,{ }^{\star \star} P<0.05,{ }^{\star} P<0.1$.

3 where only domestic Islamist attacks are included and in model 4 where domestic Islamist attacks are excluded. In Tobit estimates, the coefficient of domestic attacks is again insignificant, for both Islamist and non-Islamist terrorist events.

In Appendix A, we also replicate model 2 with the other two independent variables considered in Choi's paper, namely the total number of international terrorist incidents, and the total number of terrorist groups. Both OLS and two-limit Tobit estimates do not display any significant coefficient. This result is consistent with Choi's result for international terrorism, but not with the total number of terrorist groups. Also in this case, the share of Islamist terrorist groups among is much higher after 1990 and, if there were a causal link, the correlation would have been stronger during this period.

Contrary to Choi's, our findings suggest that terror events are not associated with the size of the Muslim population globally, even when Islamist terror events are exclusively considered. The tentative reasons explaining our difference in results have been exposed in the preceding sections. Although Islamist terrorist attacks are likely to attract violent people and, in some cases, to cause their conversion to Islam, they have probably also the reverse effect: they can repel Muslim people, and can lead some of them to distance themselves from Islam.

Building on these results, it is possible to take into account our two main points of critique of Choi's theoretical argument, namely that (a) rare micro-level trajectories of conversion triggered by terror attacks can't be easily generalized to massive ones visible at the macro-level and (b) the negative impact of attacks on people's religious affiliation should be accounted for. Doing so would allow one to more carefully assess Choi's argument according to which people can feel sympathy for Muslims when they perceive that Muslim men and women are treated unfairly and unequally (Choi, 2021: 4). In such 
situations, more people can justify Islamist attacks leading ultimately the number of people inspired by these attacks to overwhelm those outraged. Yet, a rigorous identification of such situations would imply to fundamentally rethink the research design and data used. However, based on Choi's database, expanded by our own data, it is possible to rely on some proxies of such situations.

For the following analyses, we created a dummy variable coded 1 if in the previous year a country has experienced more than one non-Islamist terror attack (dummy attacks) and then interacted it with Islamist terror attacks to isolate contexts where Islamist attacks may attract more people than they repel.

Our logic is twofold. First, we argue that contexts characterized by a high level of political violence may increase people's level of tolerance for terrorism and lead them to perceive Islamist terrorism as more understandable than in less violent contexts. This would, in turn, make less people outraged by the use of terrorist tactics and, given the overall level of violence, more people could be attracted by violent strategies. Second, some non-Islamist terror attacks - that our data do not allow identifying - may target Muslim populations based on a far right or Islamophobic agenda. This would lead people to perceive Islamist terror attack as a legitimate form of retaliation.

Model 1 in Table 2 shows that, in the presence of an overall climate of violence, the coefficient of Islamist domestic terrorist attacks is significantly different from zero. This suggests that, in these specific situations, there is a correlation between the growth of Muslim populations and Islamist terrorism. Interestingly, when a country does not have experienced two or more non-Islamist attacks in the previous year, the coefficient of Islamist attacks become negative, while not reaching conventional significance thresholds. In peaceful societies, Islamist attacks do not increase the size of the Muslim population and it is even possible that they decrease it.

Comparatively, model 2 presents the symmetric estimates. Non-Islamist attacks are not correlated with the growth of Muslim populations, either after Islamists have attacked at least twice the previous year or when they do not.

These estimates shed new light on Choi's findings and provide three new insights. First, when the main flaws of the author's research design are taken into account - isolation of the effect of Islamist attacks and redefinition of the timeframe to better reflect the predominance of Islamist terrorism - the correlation between Islamist attacks and the growth of the Muslim population does not hold anymore. Second, when the theoretical limitations of the paper considered - albeit in a rough way - some empirical clues support the possibility of such a correlation but in very specific contexts characterized by a high level of political violence and the occurrence of non-Islamist attacks possibly targeting Muslims. Third, our results can explain why Choi finds a correlation between domestic terrorist attacks and the growth of the Muslim population. He attributes this result to the fact that terrorist attacks are a proxy of Islamist attacks. We, however, demonstrate that this is not the case. Our results show that Islamist attacks are correlated with an increase of the Muslim population only if non-Islamist attacks have also occurred. This means that, over a long period, a variable that confounds Islamist and non-Islamist attacks may be significant, because it simultaneously captures contexts where non-Islamist violence is high and the existence of Islamist attacks.

These clues should lead to a more careful narrative: terror attacks can produce a large wave of conversion into Islam but only in the rare instances where people feel the use of Islamist violence is legitimate. We offer these results in an attempt of triggering a constructive discussion on an important topic. Yet, they should be interpreted with caution because of the strong limitations of the research design. We replicated the results on a very short timeframe characterized by a limited number of Islamist terror attacks. Moreover, the control variables used are rough proxies and neglect some plausible alternative explanations were discussed in the first section of the paper.

\section{Conclusion}

Since $9 / 11$, the study of terrorism - and especially, Islamist terrorism - has sparked considerable scholarly interest particularly in the USA. This renewed interest in the study of political violence 
Table 2. Interaction between Islamist and non-Islamist terrorist attacks

\begin{tabular}{|c|c|c|}
\hline & $\begin{array}{l}(1) \\
\text { Islamist domestic terrorist attacks } \\
\text { Non-Islamist dummy attacks }\end{array}$ & $\begin{array}{l}\text { Non-Islamist domestic terrorist attacks } \\
\text { Islamist dummy attacks }\end{array}$ \\
\hline Domestic terrorist attacks $_{i t-1}$ & $\begin{array}{c}-0.287 \\
(0.217)\end{array}$ & $\begin{array}{c}0.037 \\
(0.037)\end{array}$ \\
\hline Dummy attacks $_{i t-1}$ & $\begin{array}{c}-0.112 \\
(0.145)\end{array}$ & $\begin{array}{c}-0.167 \\
(0.238)\end{array}$ \\
\hline Domestic terrorist attacks $\times$ Dummy attacks & $\begin{array}{l}0.552^{\star \star} \\
(0.269)\end{array}$ & $\begin{array}{c}0.116 \\
(0.086)\end{array}$ \\
\hline${\text { Fertility } \text { rate }_{i t-1}}$ & $\begin{array}{c}0.468 \\
(0.297)\end{array}$ & $\begin{array}{c}0.492^{*} \\
(0.292)\end{array}$ \\
\hline College education $_{i t-1}$ & $\begin{array}{c}-0.124 \\
(0.495)\end{array}$ & $\begin{array}{c}-0.122 \\
(0.496)\end{array}$ \\
\hline 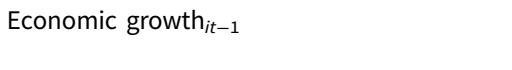 & $\begin{array}{c}0.495 \\
(0.606)\end{array}$ & $\begin{array}{c}0.498 \\
(0.611)\end{array}$ \\
\hline Democracy $_{i t-1}$ & $\begin{array}{c}0.055 \\
(0.048)\end{array}$ & $\begin{array}{c}0.056 \\
(0.048)\end{array}$ \\
\hline Political instability $y_{i t-1}$ & $\begin{array}{c}-0.005 \\
(0.017)\end{array}$ & $\begin{array}{c}-0.009 \\
(0.018)\end{array}$ \\
\hline Civil war $_{i t-1}$ & $\begin{array}{c}0.219 \\
(0.186)\end{array}$ & $\begin{array}{c}0.205 \\
(0.185)\end{array}$ \\
\hline Constant & $\begin{array}{l}21.985^{\star \star \star} \\
(5.691)\end{array}$ & $\begin{array}{l}21.795^{\star \star \star *} \\
(5.742)\end{array}$ \\
\hline$R^{2}$ & & \\
\hline Within & 0.09 & 0.09 \\
\hline Between & 0.01 & 0.00 \\
\hline Overall & 0.00 & 0.00 \\
\hline Observations & 2280 & 2281 \\
\hline
\end{tabular}

Standard errors are in parentheses.

${ }^{\star \star \star} P<0.01,{ }^{\star \star} P<0.05,{ }^{\star} P<0.1$.

has led to positive outcomes and allowed unpacking the strategic dynamic of terrorism, notably by embedding terrorist tactics in asymmetrical warfare strategies. Yet, the growing attention to terrorism has also generated a large number of problematic studies, characterized by fuzzy concepts, sloppy theoretical generalizations, and inadequate research design. Criticism has predominantly targeted the quantitative study of terrorism, suspected of making hasty generalization based on spurious correlations (see, among others, Jackson et al., 2009). We believe that these critiques very often fail to come up with compelling arguments. This does not mean that they always miss the point and we believe Choi's recent publication exposes itself to this kind of criticism.

In this comment piece, we have strived to come with a constructive assessment of the value and limitations of the paper. Although we believe that the point of departure of the paper - the investigation of the impact terror campaigns have on militants' recruitment - is well grounded and relevant, we also think that the theoretical framework and empirical design of the paper do not give justice to this focus.

First, we would like to see Choi's paper be more prudent in his theoretical ambition. If it is attested that terror attacks lead some radical individuals to join the ranks of Islamist groups, there is no reason to think such trajectories are so massive that they triggered a fourth wave of Islamization. The number of Muslim people being repelled by such attacks is likely to be much larger than the new converts. More attention should also be given to the role of hidden variables - such as discrimination - likely to explain the growth of the Muslim population and terror attacks in two distinct manners.

Second, we believe that ambitious theoretical arguments call for rigorous empirical tests. In that regard, the analysis of the impacts of all terror events over a time period characterized by the activism of domestic far-left and secessionist groups should, at least, invite to be extremely cautious in the interpretation and generalization of the results. The conceptual arguments invoked to support this selection 
of cases - namely that people associate Islam with terrorism for unfounded reasons - could have been more rigorously thought about, especially in light of the timeframe used. Our commentary shows that when using a refined research design distinguishing between Islamist and non Islamist terror events and using a timeframe where Islamist attacks were predominant, the observed correlation does not hold anymore. Yet, our replication of Choi's analyses allows us to identify some clues of the possibility of such correlation but only for contexts where political violence is intense enough to be considered as a legitimate strategy.

We hope that our commentary will lay the ground for a discussion on the criteria for a sound production of scientific knowledge on terrorism. Producing rigorous research is even more important as research on terrorism is increasingly used by policy-makers to design counter-terrorist agenda. Hasty research is, in this context, likely to lead to hasty policies likely to make the situation of people - and especially Muslims - worse than it currently is.

Supplementary material. The supplementary material for this article can be found at https://dataverse.harvard.edu/dataset. xhtml?persistentId=doi:10.7910/DVN/EW3JWI.

\section{References}

Balcells L and Torrats-Espinosa G (2018) Using a natural experiment to estimate the electoral consequences of terrorist attacks. Proceedings of the National Academy of Sciences 115, 10624-10629.

Barceló J and Labzina E (2020) Do Islamic State's deadly attacks disengage, deter, or mobilize supporters? British Journal of Political Science 50, 1539-1559.

Benmelech E and Klor EF (2020) What explains the flow of foreign fighters to ISIS? Terrorism and Political Violence 32, $1458-1481$.

Bongar B, Brown LM, Beutler LE, Breckenridge JN and Zimbardo PG (eds.) (2006) Psychology of Terrorism. Oxford: Oxford University Press.

Brown D and James P (2018) The religious characteristics of states: classic themes and new evidence for international relations and comparative politics. Journal of Conflict Resolution 62, 1340-1376.

Choi S (2021) Terrorist campaigns and the growth of the Muslim population. Japanese Journal of Political Science 22, 40-56.

Choi SW and Piazza JA (2017) Foreign military interventions and suicide attacks. Journal of Conflict Resolution 61, 271-297.

Crenshaw M (2007) The logic of terrorism. Terrorism in Perspective 24, 24-33.

De la Calle L and Sanchez-Cuenca I (2013) Killing and voting in the Basque country: an exploration of the electoral link between ETA and its political branch. Terrorism and Political Violence 25, 94-112.

Egger C and Magni-Berton R (2021) The role of Islamist ideology in shaping Muslims believers' attitudes toward terrorism: evidence from Europe. Studies in Conflict \& Terrorism 44, 581-604.

Egger C, Magni-Berton R and Varaine S (2020) Jihadism without borders: the rise of foreign fighters, affiliated terrorists and lone wolves outside civil wars. Advance. Preprint. https://doi.org/10.31124/advance.12696857.v1

Enders W, Sandler T and Gaibulloev K (2011) Domestic versus transnational terrorism. Journal of Peace Research 48, 319337.

Ghandour A-R (2002) Jihad Humanitaire: Enquête sur les ONG Islamiques. Paris: Flammarion.

Ghatak S (2016) Challenging the state: effect of minority discrimination, economic globalization, and political openness on domestic terrorism. International Interactions 42, 56-80.

Ghatak S and Prins BC (2017) The homegrown threat: state strength, grievance, and domestic terrorism. International Interactions 43, 217-247.

Gould ED (2019) Explaining the unexplained: residual wage inequality, manufacturing decline and low-skilled immigration. The Economic Journal 129, 1281-1326.

Grynkewich AG (2008) Welfare as warfare: how violent non-state groups use social services to attack the state. Studies in Conflict \& Terrorism 31, 350-370.

Institute for Economics and Peace (2016) Global Terrorism Index 2016. New York: Institute for Economics and Peace.

Jackson R, Breen Smyth M and Gunning J (eds.) (2009) Critical Terrorism Studies: A New Research Agenda. Oxfordshire: Routledge.

Karagiannis E (2012) European converts to Islam. Politics, Religion \& Ideology 13, 99-113.

Kibris A (2011) Funerals and elections: the effects of terrorism on voting behavior in Turkey. Journal of Conflict Resolution 55, 220-247.

Kydd A and Walter B (2006) The strategies of terrorism. International Security 31, 49-80.

LaFree G and Dugan L (2007) Introducing the global terrorism database. Terrorism and Political Violence 19, $181-204$. 
LaFree G and Dugan L (2016) Global terrorism and the deadliest groups since 2001. In, Backer D, Bhavnani R and Huth P (eds), Peace and Conflict 2016. Oxfordshire: Routledge, pp. 69-70.

LaFree G, Dugan L and Miller E (2019) Putting Terrorism in Context: Lessons From the Global Terrorism Database. Oxfordshire: Routledge.

Pape RA (2003) The strategic logic of suicide terrorism. American Political Science Review 97, 343-361.

Piazza JA (2011) Poverty, minority economic discrimination, and domestic terrorism. Journal of Peace Research 48, 339-353.

Piazza JA (2012) Types of minority discrimination and terrorism. Conflict Management and Peace Science 29, 521-546.

Polo SM and Gleditsch KS (2016) Twisting arms and sending messages: terrorist tactics in civil war. Journal of Peace Research 53, 815-829.

Poston DL, Chang CF and Dan H (2006) Fertility differences between the majority and minority nationality groups in China. Population Research and Policy Review 25, 67-101.

Rambo LR and Farhadian CE (eds.) (2014) The Oxford Handbook of Religious Conversion. Oxford: Oxford Handbooks.

Roy O (2017) Jihad and Death: The Global Appeal of Islamic State. Oxford: Oxford University Press.

Sander A (2006) Experiences of Swedish Muslims after the terror attacks in the USA on 11 September 2001. Journal of Ethnic and Migration Studies 32, 809-830.

University of Maryland (2019) Global Terrorism Overview: Terrorism in 2019, Maryland: START, https://www.start.umd.edu/ pubs/START_GTD_GlobalTerrorismOverview2019_July2020.pdf

Varaine S (2020a) Revisiting the economics and terrorism nexus: collective deprivation, ideology and domestic radicalization in the US (1948-2016). Journal of Quantitative Criminology 36, 1-33.

Varaine S (2020b) The compass of violence: prosperity, decline and the ideological orientation of radical movements. (PhD Dissertation). Political science. Université Grenoble Alpes.

Varaine S, Benslimane I, Magni-Berton R and Crosetto P (2021) Attacking the weak or the strong? An experiment on the targets of parochial altruism. Political Behavior, 1-32. https://doi.org/10.1007/s11109-021-09696-9

Wilson B and Kuha J (2018) Residential segregation and the fertility of immigrants and their descendants. Population, Space and Place 24, e2098. 


\section{Appendix A}

Table A1. Replication of Choi's model restricted to the period 1991-2007 for the total number of international terrorist incidents and the total number of terrorist groups

\begin{tabular}{|c|c|c|c|c|}
\hline & $\begin{array}{c}(1) \\
\text { OLS 1991-2007 }\end{array}$ & $\begin{array}{c}(2) \\
\text { OLS 1991-2007 }\end{array}$ & $\begin{array}{c}(3) \\
\text { Tobit } 1991-2007\end{array}$ & $\begin{array}{c}(4) \\
\text { Tobit } 1991-2007\end{array}$ \\
\hline International terrorist incidents $s_{i t-1}$ & $\begin{array}{l}0.008 \\
(0.054)\end{array}$ & & $\begin{array}{l}0.001 \\
(0.047)\end{array}$ & \\
\hline Number of terrorist organizations ${ }_{i t-1}$ & & $\begin{array}{c}0.025 \\
(0.083)\end{array}$ & & $\begin{array}{c}0.023 \\
(0.070)\end{array}$ \\
\hline Fertility rate $_{i t-1}$ & $\begin{array}{r}0.495^{\star} \\
(0.288)\end{array}$ & $\begin{array}{l}0.495^{\star} \\
(0.291)\end{array}$ & $\begin{array}{l}0.492^{\star * \star} \\
(0.102)\end{array}$ & $\begin{array}{l}0.492^{\star * *} \\
(0.102)\end{array}$ \\
\hline College education $_{i t-1}$ & $\begin{array}{c}-0.124 \\
(0.495)\end{array}$ & $\begin{array}{c}-0.124 \\
(0.495)\end{array}$ & $\begin{array}{c}-0.129 \\
(0.086)\end{array}$ & $\begin{array}{l}-0.130 \\
(0.086)\end{array}$ \\
\hline Economic growth $_{i t-1}$ & $\begin{array}{c}0.493 \\
(0.608)\end{array}$ & $\begin{array}{c}0.493 \\
(0.609)\end{array}$ & $\begin{array}{l}0.496^{\star \star \star} \\
(0.167)\end{array}$ & $\begin{array}{l}0.496^{\star \star \star} \\
(0.167)\end{array}$ \\
\hline Democracy $_{i t-1}$ & $\begin{array}{l}0.055 \\
(0.048)\end{array}$ & $\begin{array}{c}0.055 \\
(0.048)\end{array}$ & $\begin{array}{l}0.057^{\star \star \star} \\
(0.012)\end{array}$ & $\begin{array}{l}0.057^{\star \star \star} \\
(0.012)\end{array}$ \\
\hline Political instability $y_{i t-1}$ & $\begin{array}{c}-0.007 \\
(0.018)\end{array}$ & $\begin{array}{c}-0.007 \\
(0.018)\end{array}$ & $\begin{array}{c}-0.007 \\
(0.010)\end{array}$ & $\begin{array}{c}-0.007 \\
(0.010)\end{array}$ \\
\hline Civil war $_{i t-1}$ & $\begin{array}{c}0.206 \\
(0.183)\end{array}$ & $\begin{array}{c}0.205 \\
(0.183)\end{array}$ & $\begin{array}{c}0.210 \\
(0.235)\end{array}$ & $\begin{array}{c}0.208 \\
(0.235)\end{array}$ \\
\hline Constant & $\begin{array}{l}21.872^{\star \star \star} \\
(5.718)\end{array}$ & $\begin{array}{l}21.864^{\star \star \star} \\
(5.731)\end{array}$ & $\begin{array}{l}1.344^{\star \star \star} \\
(0.040)\end{array}$ & $\begin{array}{l}1.344^{\star \star \star} \\
(0.040)\end{array}$ \\
\hline \multicolumn{5}{|r|}{ ) (טד. } \\
\hline Within & 0.09 & 0.09 & & \\
\hline Between & 0.00 & 0.00 & & \\
\hline Overall & 0.00 & 0.00 & & \\
\hline Pseudo- $R^{2}$ & & & 0.690 & 0.690 \\
\hline Country fixed effects & Yes & Yes & Yes & Yes \\
\hline Year Fixed effects & Yes & Yes & Yes & Yes \\
\hline Obs. & 2281 & 2281 & 2281 & 2281 \\
\hline
\end{tabular}

Standard errors are in parentheses.

${ }^{\star \star \star} P<0.01,{ }^{\star \star} P<0.05,{ }^{\star} P<0.1$.

Cite this article: Egger C, Magni-Berton R (2021). Terrorist campaigns and the growth of the Muslim population: a reply. Japanese Journal of Political Science 22, 369-380. https://doi.org/10.1017/S1468109921000165 